\title{
The Ozonation as Competitive Advantage in Post-Harvest Treatment of Tomato
}

\section{Rogério Simão}

\author{
Federal University of Rondônia (Brazil)/ Department of Accounting Science \\ rogermcgoo@unir.br \\ Diogo Gonzaga Torres Neto
}

Federal University of Rondônia (Brazil)/Department of Business Administration

diogo@unir.br

\section{Cleberson Eller Loose}

Federal University of Rondônia (Brazil)/ Department of Accounting Science clebersonloose@unir.br"

\section{Doi:10.5901/mjss.2015.v6n1s1p529}

Abstract

This paper intent to show the competitive advantages created by ozonation treatment in tomatoes during storage logistic postharvest. These advantages have been verified by carrying out a physical-chemical in samples of Deborah tomato varieties from sector vegetable farmer in Porto Velho - $R O$ and a survey of tomato traders in the region. At first, tomatoes were brought to the laboratory of biochemistry at São Lucas College, separated into two groups: a test and a control. Tomatoes from the test group were exposed to a continuous flow of ozone at a concentration of about $1 \mathrm{ppm} / \mathrm{vol}$ ), $25^{\circ} \mathrm{C} \pm 3{ }^{\circ} \mathrm{C}$ temperature and $85 \% \pm 10 \%$ relative humidity for 24 hours inside a chamber treatment. When compared with tomatoes in the control group (no treatment), the test group lost only $2.28 \%$ of its fresh weight against $8.93 \%$, the $\mathrm{pH}$ levels and vitamin C were stable during storage; maturation (color) was delayed by two days and at the end of the experiment, $14 \%$ of treated tomatoes were shown to be unfit for consumption while $70 \%$ of untreated tomatoes had to unsuitable for consumption. According to laboratory results, it was found that the tomato ozonized could offer benefits to traders of the product, because losses were reduced and the gains were $43 \%$ higher than the untreated tomatoes.

Keywords: production Management; value chain; post-harvest losses; ozone; storage.

\section{Introduction}

Recent studies on the conservation of fresh tomato (Lycopersicon esculentum Mill.) has shown great concern for the maintenance of the quality of the product during the storage process. The logistics in this stage of marketing is to keep the product fresh and of good appearance for the consumption of more time.

The tomatoes, being a climate product, i.e. maintain a metabolic activity normal after their harvest, need special care, because the chemical transformations in their composition are due to its ability to absorb oxygen. Therefore, depending on the time of storage, the tomato loses weight, which reduces its commercial value due to brown rot. Soon after comes into senescence, it rots and the loss is total.

Production Management and operations is the administration of the system of production of an organization that transforms inputs into products and services of the organization (GAITHER 2002).

According to Davis (2001), under a corporate perspective, the administration of the production can be defined as the management of direct resources that are needed to obtain the products and services of an organization.

Companies and organizations understand that the logistics activities can provide competitive advantage, because it adds value to the product. This value is expressed mainly in terms of time and place, while the transport adds value of place, stocking adds value of time. To have value to the customer, the product must be available when and where the customer wants to (BATALHA, 2004). 
For both, a logistics of maintaining the quality of these products should be very specific to this sector, because the losses can be very high in a short period of time.

Thus, the logistics, have a fundamental role in the whole production chain, because it is responsible for maintaining what you want at the desired location in a timely manner. However, the logistics are being defined as:

"Part of the process of supply chain management, which deals with the planning, implementation and control efficient and effective flow and storage of goods, services, and related information, from its point of origin to its point of consumption in order to fully satisfy the needs of customers (Council of Logistics Management apud Silva 2000: p. 20).

According Batalha (2007), logistical system customers match the final destination of a delivery. Retailers, wholesalers, a factory, or a tank are seen as final consumers of an organization, therefore, customers of the organization. In this sense, the objective of logistics management is to deal with the customer as the focus of the business, not by measuring efforts for which he is met at the time, the place and the desired condition.

Bowersox \& Observations by Wolfgang Closs (2001) emphasizes that the logistics competence of a company is to provide the customer with a service competitively higher than the lowest possible total cost.

The correct use of this competence logistics gives the company competitive advantage for a process universally adopted by all companies that is the creation of value for the customer. One of the competencies necessary to create value for the customer is the logistics (BOWERSOX \& CLOSS, 2001).

Among the primary activities of the value chain, is the internal logistics, a place where you can enter the treatment of perishable products such as tomatoes. To Porter (1989, p. 36), the internal logistics is one whose operations are associated with the receipt, storage and distribution of inputs in to the product, such as a different treatment to reduce losses, for example, since the process of transformation of products consumed in natura is its conservation to be consumed.

Storage can also be part of the production process, there are cases in which the product must be aging (wines and cheeses) or mature (fruit) before being delivered to the customer (BATALHA, 2007). The storage is also related to the location of the premises, this should be a strategic location that favors the marketing and transport of raw materials and finished products (GOMES, 2004).

Even the companies adopting another distribution structure, as occurs with the distribution of food and other nondurable consumer goods, where consumers can buy products in large retail shops in retail minors or directly with the rural producer (BATALHA, 2007), the process of conservation of these products and the creation of value for the customer will be possible.

The non-perception of value can be seen as a failure of the market. According Zylberzstajn and Neves (2000), the consumer tends not to reward the high quality of the products, I'm not able to distinguish them from inferior quality products.

Thus, it's necessary to know which are the activities that really are collaborating to improve the quality of the product and contribute to the generation of value to the customer. What happens is that the value is the perception of customers in relation to their specific expectations, because it is not always added value is perceived value, even if available (SILVEIRA \& EVRARD 2002).

However, when a company seeks differentiate themselves on the basis of logistic services, it must offer a competitive service at the lowest possible cost, including logistical efforts with a focus on speed, flexibility, and availability of the product where and when the customer wants (BATALHA 2007).

In the centers of supplies, the tomatoes are again classified as to color, size, format, and range. This reclassification is necessary, because each customer requires a type of tomato for marketing. Fruit transported over long distances should be in green color and be of type long life, those intended for the local consumption can be normal and be in green color-mature. The transport must be carried out in trucks type refrigerators and the load may not be mixed with other plant. The fruits of tomato plants are highly perishable and film quite thin, becoming a product very fragile for handling logistics, therefore should be consumed as soon as possible (FERREIRA et al. 2008).

To increase the shelf life of the fruit and reduce losses are used cold chambers. Ferreira (2003) showed that in order to remain in the market, wholesale Company of Warehouses and General stores in São Paulo (CEASA) would be interested in using the cold chain for fruit and vegetables. Tomatoes that are not cooled must be consumed by up to five days.

However, Luengo (2001) highlights 3 techniques for the storage of crops: cold chamber, controlled atmosphere and irradiation. The latter is still not widespread globally, because your deployment cost is high and requires centralization of supply. According to the author, tomatoes can be stored in cold rooms at temperatures ranging from $13 \mathrm{C}$ 
to $21 \mathrm{C}$ for a period of 5 to 20 days, depending on the stage of maturity where they are. He emphasized that only healthy fruits can be stored, because low temperature does not destroy pathogens, only decreases its activity. This technique of cooling does not improve the quality of the plant, only preserves the

Therefore, the purchase decision is given by the evaluation of some aspects of the product that lead the consumer to believe that, on the basis of a combination of appearance, color, and firmness, the product will be more tasty.

The post-harvest treatment is a constant concern in the logistics of perishable products and have aroused interest of researchers from a wide range of areas. Thus, many studies have been conducted on the use of ozone gas (O3) as an alternative to the logistics of stocking up on food and in conservation of vegetables and fruits for consumption in natura (XU 1999).

Second Rice et al. (1982) one of the most important effects of ozone in refrigerated storage is to retard the process of ripening of fruits and vegetables. According to the author, many fruits like banana and apple release the gas Ethylene $\left(\mathrm{CH}_{2}=\mathrm{CH}_{2}\right)$, which is responsible for speeding up the process of maturation. Ozone is very effective in the removal of ethylene through chemical reaction, the effect of this reaction can increase the shelf life of many fruits and vegetables.

Some products such as: apple, persimmon, strawberries and raspberries, lemons and oranges were treated with ozone by several researchers (PUIA 2004; SALVADOR 2006; BIALKA 2007; PALOU 2001), respectively. This treatment served both to control the proliferation of fungi and bacteria (plant health) as well as for the extension of shelf life.

Thus, the objective of this work was to verify the competitive advantages and creation of value derived from the process of ozonation of tomatoes during the period of logistical storage after harvest.

\section{Materials and Methods}

Plant Material - For the experiments, we chose the tomato. This term is used by producers and distributors of tomatoes to differentiate the tomatoes marketed to the industry in obtaining of pulp and juice of tomatoes sold for consumption in natura as salad (tomato). The stage of maturation is the most appropriate mature-green (salad), figure 1.

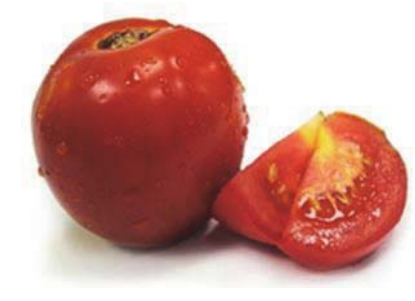

Figure 1 - tomatoes in stage mature green.

Source - CEAGESP, 1998.

The tomatoes were purchased as follows: variety Deborah from industry lumberjacks in the municipality of Porto Velho RO in the months of May and June of 2009. In the selection, we chose to tomatoes in stage mature green, taking into account the point of commercial harvest. The collections were always in the first hours of the day, allowing the product was ready for the experiments at 10:00 a.m. in the morning. The fruits were selected with good standard of quality, free from defects, injuries or diseases. After the selection, the tomatoes were rinsed in tap water, separated into two groups with equivalent characteristics statistically as the physico-chemical properties and packaged in plastic pots $45 \mathrm{~L}$ capacity. Each group was composed of 50 units each. The material was taken to the laboratory of biochemistry Faculty are Lucas - RO, where assays were performed. One of the groups called test was subjected to treatment with ozone during $24 \mathrm{~h}$ and another group called control was without treatment. Of the 50 units, 16 were used for the analyzes of vitamin $\mathrm{C}$ and $\mathrm{pH} 4$ for the analysis of mass loss and the 30 remaining for the analysis of senescence and injury. Tomatoes from the test group were exposed to a continuous flow of ozone of approximately $1 \mathrm{ppm}(\mathrm{vol} / \mathrm{vol})$, temperature of $25^{\circ} \mathrm{C} \pm 3{ }^{\circ} \mathrm{C}$ and relative humidity of $85 \% \pm 10 \%$ during $24 \mathrm{~h}$ within a chamber of treatment. After they were stored in the laboratory for 14 days, under the same conditions of temperature and relative humidity.

Obtaining ozone - ozone gas was obtained by means of an ozone generator in gaseous form through the corona effect. Nottingham (2003) presents an ozone generator of low consumption, aiming at applications for small businesses. For the construction of the circuit high-voltage generator, resorted to a specialist in electronics for guidance on the acquisition of appropriate material and assemble the project. The assembly and operation of the complete circuit are in Braga (1986). 
Storage - storage occurred in the laboratory itself, because the temperature could be maintained at about $25 \mathrm{C}$ and the pots were kept open so that the concentration of ethylene is not partial damaging results. During this period of 14 days, the conditions of conservation of tomatoes were controlled so as not to leave diseased fruits with healthy fruits.

Physical and chemical Properties - The parameters of quality of tomato were evaluated from the chemical and physical analysis carried out in the laboratory of biochemical analyzes, including weight loss, color, Ph, senescence, injury and ascorbic acid (vitamin C). The samples of the product were evaluated at intervals that represent a real change in behavior of the product through the process of ozonation, which in this case was two in two days. All chemical analyzes were performed according to the procedure described by Carvalho (1990) and by the Association of Official Analytical Chemistry, AOAC (1997).

Loss of mass - the fruits were weighed with a scale mark ECNAL model Mark 2200 with maximum load of $2200 \mathrm{~g}$ at minimum of $200 \mathrm{mg}$. The loss of fresh weight was determined by the formula :

$M p=\frac{M i-M f}{M i} \times 100$

$\mathrm{Mp}=$ Percentage of mass loss of the fruit.

$\mathrm{Mi}=$ mass of fruits at the beginning (in grams).

$\mathrm{Mf}=$ mass of fruit at the end (in grams).

Color - this parameter was assessed in visual way, according to the classification of tomatoes as the color (figure 2), proposed by CEAGESP and the Secretary of Agriculture and Supply in the State of Sao Paulo (1998). samples were photographed with digital camera Sony model DSC-W110 with 7.2 mega pixels resolution.

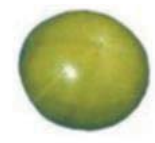

Green (1)

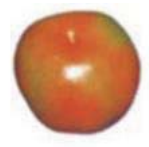

salad (2)

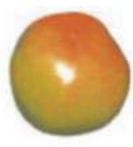

colored (3)

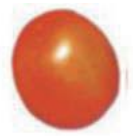

mature (4)

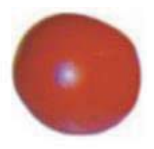

sauce ( 5$)$

Figure 2 - Classification of tomatoes as the color. State of Rondônia (Brazil). Source: CEAGESP (1998).

$\mathrm{pH}$ - the potential Hidrogenionic $(\mathrm{pH})$ was determined by the method eletrometric. The principle of the method is based on the determination of concentration since it arises from using the order to determine. reading was performed directly on the device. The instrument used was the EVLAB brand model EV: 03, adjusted to alkaline solutions and neutral.

Senescence - senescence was observed by brown rot of fruit. Starting in stalk and extending longitudinally.

Injuries - injury by attack of fungi and bacteria was assessed visually by the appearance of spots on the body of the fruit. These spots indicate contamination of the fruit.

Content vitamin C - (mg of ascorbic acid/ 100ml of juice) was determined using the L-ascorbic acid, since this is a compound with $100 \%$ activity of vitamin $\mathrm{C}$. The method is based on the reduction of 2,6-dichlorophenol indophenol sodium (DCFI) by ascorbic acid.

Experimental design - The experimental design was a randomized complete block that consisted of a type of treatment and three repetitions for the analyzes during the 14 days of storage. Whereas each repetition was a plot, we collected a fruit at random from each plot, and the average of its values as given end obtained that was statistically analyzed. The statistical test chosen for analysis of the physico-chemical properties was the Student's t-test for small sample with a significance of $5 \%$.

- Survey - After the experiments, analyzes were made of logistical advantages from the information provided through semi-structured interviews with a wholesaler, a supermarket manager and a distributor of tomato in fairs of Porto Velho. Were conducted two interviews: one to know the profile of tomato offered by trade and another to discuss what advantages the trader could obtain with the increase of life post-tomato harvest.

- Competitive Advantage - The competitive advantages and financial were obtained in accordance with the chain of generic value that, in an appropriate logistics, the distributor of tomato will greater advantage, because your product will have higher quality than its competitors.

\section{Results and Discussions}

Before the application of ozone, held statistical tests to prove that the initial conditions were similar in the two groups. The results showed that the samples had no significant differences for the earth, vitamin $\mathrm{C}$ content and $\mathrm{pH}$, as shown in table 
1. Regarding color, at the beginning it was 25 tomatoes colored (in stage mature-green), 5 green and no red both in the test group and the control group. The color was evaluated during the experiment and the result described in chart. For the injuries and senescence, statistical tests were carried out only after the experiment already that were not of fruit under these conditions at the beginning of the experiment in both groups.

Table 1 - average values of physico-chemical properties for the tomato Deborah before treatment with ozone.

\begin{tabular}{cccc}
\hline Group & Mass $(\mathrm{g})$ & Vitamin C $(\mathrm{mg} / 100 \mathrm{ml})$ & Ph $(-)$ \\
\hline Test & $155.18 \mathrm{a}^{1}$ & $22.46 \mathrm{a}$ & $4.32 \mathrm{a}$ \\
Control & $155.61 \mathrm{a}$ & $22.39 \mathrm{a}$ & $4.33 \mathrm{a}$ \\
\hline
\end{tabular}

${ }^{1}$ Medium followed by the same letters in columns don't differ, the $5 \%$ significance level, according to the $t$ test. Source: Survey data by authors.

After the treatment with ozone, the analysis showed, with the aid of graphics, the behavior of the attributes of quality of fruit over time that lasted the test trial. The following were carried out statistical analyzes of these attributes until the sixth day of storage, because from the 6 day it was considered that the conditions of control given by environment reached its maximum point, in relation to quality, whereas that from this date the fruits could not display appropriate conditions of consumption. The end of the experiment took place when the mass loss reached levels above $5 \%$, signifying that from this level the appearance of the fruit was compromised thereby indicating, not conditions of sale of the product to the consumer. The experiment lasted for a few more days to test the exhaustion of fruit treaty.

In addition to the results until the sixth day of storage, was evaluated at the end of the experiment, on the 14th day of storage, through statistical analysis, the qualities of the tomato in the two groups. With the purpose to prove the efficiency of ozone for a longer period, comparing, in this step, the mass loss, vitamin $\mathrm{C}$, pH and percentage of injury and senescence between groups.

Starting with the weight loss, it can be observed, with the aid of graph 1, that the fruit in the two groups are losing weight according to the days of storage, and that the control group presented higher values than the test group. This showed the importance of the implementation of the ozone gas at the beginning of the storage to the tomato.

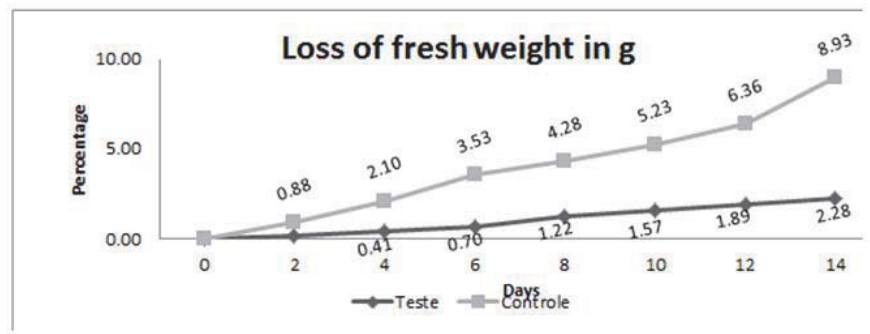

Graph 1 - Weight Loss for the tomato Deborah.

Source: Survey data by authors.

Note that the decrease in the loss of mass provides competitive advantage, because the trader will make for a better quality product for consumers.

Continuing with the analysis and comparing the beginning and the 6 day of storage, the tomatoes from the control group showed greater weight loss and differed significantly at $5 \%$ level of probability, which did not occur with the tomatoes from the test group, as can be seen in table 2 .

Table 2 - average values of physico-chemical properties for the tomato Deborah at the beginning and in the 6th day of storage.

\begin{tabular}{cccc}
\hline \multirow{2}{*}{ Storage } & Fresh mass Loss (\%) & Vitamin C $(\mathrm{mg} / 100 \mathrm{ml})$ & PH $(-)$ \\
& Control test & Control test & Control test \\
\hline Beginning & $0.00 \mathrm{a}^{1} 0.00 \mathrm{a}$ & $22.46 \mathrm{a} \mathrm{22.39 \textrm {a }}$ & $4.32 \mathrm{a} \mathrm{4.33 \textrm {a }}$ \\
6 Day & $0.70 \mathrm{~b} \mathrm{3.53 \textrm {b }}$ & $22.39 \mathrm{~b} \mathrm{19.20} \mathrm{b}$ & $4.31 \mathrm{~b} \mathrm{4.16} \mathrm{b}$ \\
\hline
\end{tabular}

1 Medium followed by the same letter in columns do not differ, the $5 \%$ significance level, according to the $t$ test

Source: Survey data by authors. 
When we assessed the entire period, 14 days of storage, the results showed that the fruit that had been ozonizados not reached the same proportions of weight loss when compared with the 6 day fruit maintained without treatment with ozone (graph 2). At $5 \%$ level of probability, the groups did not show significant difference (table 2), however, the control group in the 6th day was a loss of mass 1.5 times greater than the test group on the 14th day.

This revealed that the ozonation can reduce the loss of weight of fresh tomatoes in comparison with the loss of fresh weight of tomatoes from the control group.

Table 3 - mean values of the percentage of weight loss for the tomato Deborah in the 6 th and 14th day of storage.

\begin{tabular}{cc}
\hline Group & Weight Loss ( \%) \\
\hline Test 14 day & $2.28 \mathrm{a}^{1}$ \\
Control 6 day & $3.53 \mathrm{a}$ \\
Control 14 day & $8.93 \mathrm{~b}$ \\
\hline followed by the same letter in columns do not differ, the 5\% significance level, according to the $t$ test.
\end{tabular}

${ }^{1}$ Medium followed by the same letter in columns do not differ, the $5 \%$ significance level, according to the $t$ test.

Source: Survey data by authors.

To conclude this analysis of weight loss, and even with the aid of graph 1, at the end of the storage period (14 day) the percentage of mass loss of the tomatoes from the control group was approximately four times greater than the percentage of tomatoes from the test group, with $8.93 \%$ and $2.28 \%$ respectively, and the difference between the means was significant at $5 \%$ probability (table 3 ). Thus, the treatment with ozone was shown to be efficient in the control of fresh mass loss for the tomato Deborah.

The evaluation of $\mathrm{pH}$ showed oscillations in both groups throughout the storage period (graph 2). However, according to the degree of maturity, the levels of $\mathrm{pH}$ of tomatoes treated remained practically stable while that of the control group had a decrease since the beginning to the end of the period, with a difference of $6.24 \%$.

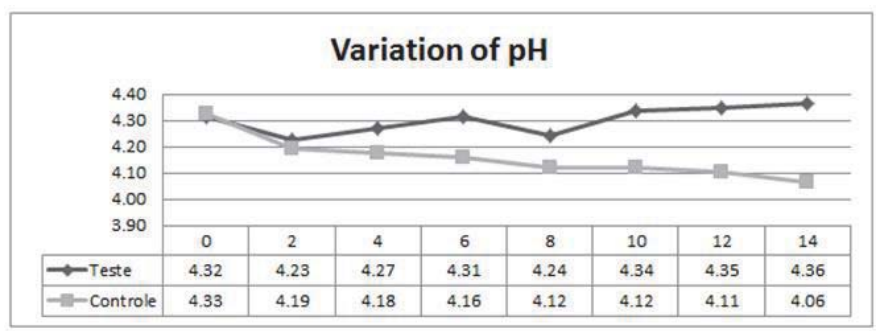

Graph 2 - Variation of $\mathrm{pH}$ for the tomato Deborah in a period of 14 days.

Source: Survey data by authors.

The maintenance of $\mathrm{pH}$ with the ozonation generates the perception of value by the customer, because this is also concerned with the chemical properties of foods.

Complementing the analysis through the statistics (table 2), the result was similar to that described for the variable mass loss, i.e. , until the sixth day, there was a significant difference only for the control group, the $5 \%$ level of probability.

Going a step further with the statistics (table 4), the levels of pH did not show significant difference until the 14th day of storage for tomatoes treated with ozone, which did not occur with the tomatoes, not treated, the $5 \%$ level of probability. The level of $\mathrm{pH}$ directly influences the taste of the fruit, the lower the $\mathrm{pH}$ more acid will be the flavor. Thus, as can be seen, the tomatoes treated with ozone remained with the flavor throughout the storage period.

Table 4 - average values of the levels of vitamin $\mathrm{C}$ and pH levels for tomatoes Deborah at the beginning and $14^{\text {th }}$ day of storage.

\begin{tabular}{ccc}
\hline Storage & Vitamin C $(\mathbf{m g} / \mathbf{1 0 0 m l})$ & ph ( $)$ \\
& Control test & Control test \\
\hline Beginning & $22.46 \mathrm{a} \mathrm{a}^{1} 22.39 \mathrm{a}$ & 4.32 to $4.33 \mathrm{a}$ \\
$14^{\text {th }}$ day & $24.26 \mathrm{~b} 14.80 \mathrm{~b}$ & 4.36 to $4.06 \mathrm{~b}$ \\
\hline
\end{tabular}

${ }_{1}^{1}$ Medium followed by the same letter in columns do not differ, the $5 \%$ significance level, according to the $t$

Source: Survey data by authors. 
For the content of vitamin C (ascorbic acid) and in accordance with the graph 3, it was observed that the levels of vitamin $\mathrm{C}$ to the tomato treaty increased compared to the beginning and the 6 day of storage and a slight decline compared to the $6^{\text {th }}$ and the 14th day. What did not occur with the tomatoes without treatment, for this group, the levels of vitamin $\mathrm{C}$ were decreasing over the period of storage.

According to table 2, it was proved that, with $5 \%$ of significance, the levels of vitamin $\mathrm{C}$ of the control group had significant difference on the sixth day of the experiment, if compared with the beginning. The trend of loss of ascorbic acid in this group continued until the end of the storage (table 4). Even with the aid of tables 2 and 4 , the tomatoes treated with ozone showed no significant difference in the levels of vitamin $\mathrm{C}$ over the period in which they were stored. The vitamin $\mathrm{C}$ suffers irreversible oxidation, losing its biological activity in fresh foods stored for long periods of time, but this did not happen in the ozonized tomato.

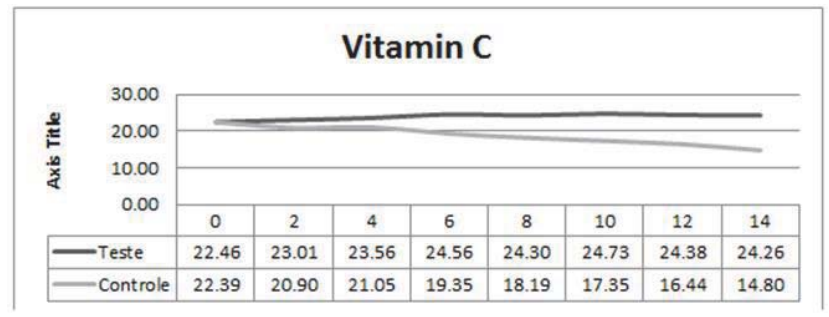

Graph 3 - content of vitamin C for the tomato Deborah in a period of 14 days.

Source: Survey data by authors.

Vitamin $C$ is one of the main chemical properties valued by consumers of fresh products. Thus, the conservation of the levels of vitamin $\mathrm{C}$ in tomatoes treated with ozone establishes the creation of value for the customer with the opportunity of obtaining a healthy product.

The results obtained in accordance with the visual analysis of color (graph 4) showed considerable differences in the process of ripening. The control group showed $100 \%$ of red color on the fifth day and $100 \%$ color sauce on the seventh day after the harvest while the test group has presented $100 \%$ of red color on the seventh day, and $100 \%$ of coloring sauce on the $10^{\text {th }}$ day of storage.

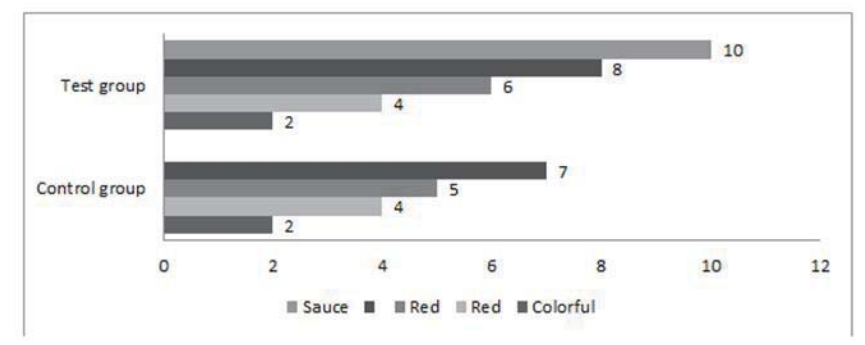

Graph 4 - maturation Level according to the color of the tomato Deborah during the experiment. Source: Survey data by authors.

There was here a competitive advantage, because the tomatoes ozonized took a little longer to mature. This causes the trader earn time in selling the product.

After the $14^{\text {th }}$ day of storage, only $10 \%$ of the fruits treated with Ozone showed some type of injury (graph 5), while $33 \%$ of the fruit not treated had some type of injury. With $5 \%$ probability, the difference is significant (table 5 ). The injuries by attack of fungi and bacteria are difficult to control in storage, because the fruit has already contaminated field. However, with the application of ozone was a decrease to the attack of these microorganisms, since its proliferation depends on factors such as the moisture in the air high and moderate temperature. 
Table 5 - average values of tomatoes that had some type of injury on the $14^{\text {th }}$ day of storage.

\begin{tabular}{cc}
\hline Groups & Tomatoes with injuries (\%) \\
\hline Test & $10 \mathrm{a}$ \\
Control & $33 \mathrm{~b}$ \\
\hline${ }^{1}$ Medium followed by the same letter in columns do not differ, the $5 \%$ significance level, according to the $t$ test .
\end{tabular}

Source: Survey data by authors.

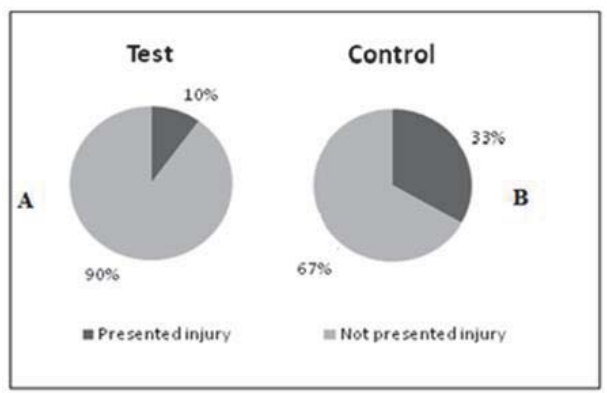

Graph 5 - injury to the Deborah tomato after 14 days stored, tomatoes treated with ozone (a) and untreated (b). Source: Survey data by authors.

As regards the senescence, it was found that, at the end of the $14^{\text {th }}$ day of storage, the sample is treated had only $4 \%$ of the fruit with wilting appearance while the sample of control had $37 \%$ of the fruit with brown rot. In general, combining injury and senescence, in accordance with the graph 6 , it has the total own tomatoes and unfit for consumption at the end of the experiment, both the test group and the control group. With 5\% probability, the difference between the averages is significant (table 6).

Table 6 - average values of tomatoes that were unfit for consumption on the $14^{\text {th }}$ day of storage.

\begin{tabular}{cc}
\hline Groups & Tomatoes unfit for consumption ( \%) \\
\hline Test & $14 \mathrm{a}$ \\
Control & $70 \mathrm{~b}$ \\
\hline
\end{tabular}

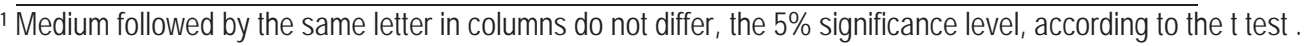

Source: Survey data by authors.

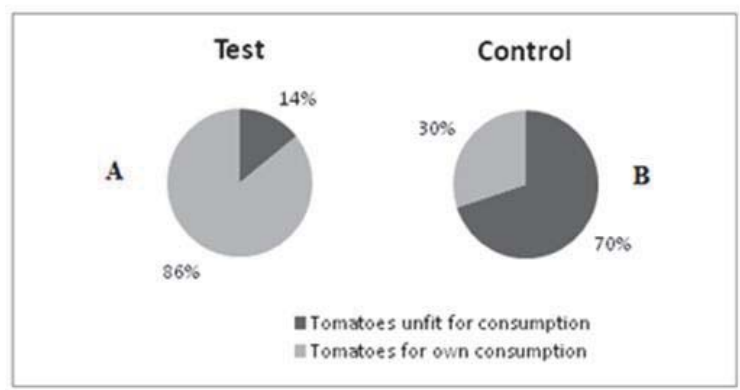

Graph 6 - tomatoes themselves and unfit for consumption after 14 days of storage, sample treated with ozone (a) and untreated (b).

Source: Survey data by authors.

The senescence, or early stage of rotting fruit, is that indicates the end of shelf life. When you start, it is a sign that the tomatoes must be discarded and not put more available to the customers.

As the injury and senescence indicates the end of the shelf life of tomatoes, the decrease of them through 
ozonation suggests the generation of competitive advantage in the produce sector, therefore, is to reduce the losses is a fundamental factor in the marketing of perishable products such as tomatoes.

However, before you begin the experiments with the tomatoes, the local market has been consulted in respect of logistic conditions of the product. Such conditions as acquisition, storage time, costs, quality, variety of greater acceptance, origin among others were the most exploited. According to the answers given by the tenants, in Porto Velho tomatoes produced in the region is not sold on a large scale, at least he is not accepted by large supermarkets in town, being only found in fairs. The tomatoes more found in large supermarkets is the variety Carmem coming from the southeast and Midwest.

Taking into account that the experiment conducted in this work was with tomato variety of Deborah (normal) and come from local production, returned then to wholesalers and merchants for an interview regarding the product treated with ozone.

All this concern, according to the respondents, is the aspect that wilted tomatoes will acquire with the passing of days, therefore the need to sell them as soon as possible to avoid financial losses. Therefore, if they could maintain the quality of the tomatoes for some time, these losses would be greatly reduced.

Contributing with Ferreira (2003), where the tomato that does not receive differential treatment must be consumed in five days, it was noted that the low quality of the tomatoes over the period of storage provides loss of gains to traders in the sector by non-acceptance of the product by customers. Due to these factors the company must create value through logistical skills to satisfy the customer (Bowersox \&Observations by Wolfgang Closs, 2001).

The customer will be satisfied when you notice that the company has created value for it. As the value is the amount that the buyer is willing to pay for what the company offers you (PORTER, 1989), it is the customer who will pay all costs for the creation of value. Thus, the logistics activity of post-harvest treatment creates value along the chain of tomato. The value will be created by offering a higher quality product and the advantages for the opportunity of not financial losses in the value chain.

The factors that involve the generation of value and competitive advantage are many as: competitive price, low cost, immediate delivery, service and quality of the product. The logistics, but it is one of the activities that encompasses the entire course of a production system, especially in the case of perishable goods, where the quality is decisive factor at the time of purchase. Since the acquisition of raw materials, the processing and the output of the finished product, the availability of an appropriate logistics and competent, undoubtedly contributes to the generation of value for the customer.

The maintenance of the levels of ascorbic acid (vitamin $\mathrm{C}$ ) and levels of $\mathrm{pH}$ in Deborah tomato are intangible values and can only be realized by the customer if the company to ensure that the quality of your product is maintained due to the existence of these chemical properties at satisfactory levels. These chemical properties together with firmness, color ideal and free of injuries (physical properties) is that the real value of the ozonized tomato will be reached.

Consider for example a market that has a demand high enough, in such a way that the tomatoes are despised because of their appearance and not for lack of demand. According to the literature regarding losses post-harvest of tomatoes and the views of traders consulted, it is estimated that it is sold only $70 \%$ of the stock in a period of a week, due to their appearance, which is related to the loss of mass and coloring.

Whereas, from the interviews, that the average expected profit on sale is $50 \%$ on the total costs, and setting:

$\mathrm{X} \rightarrow$ Quantity of product (tomato boxes)

$\mathrm{Y} \rightarrow$ Cost of application per box of tomatoes

In the case of a product without treatment, will be sold $70 \%$. Then, the quantity sold will be : $0,70 X$ What produceswill a recipe of $1,50 * 0,70 X Y=1,05 X Y$ therefore, the actual profit of the trader will amount to only $5 \%$ of the total costs.

As the product treated with ozone has a life post-harvest of two weeks, you will not be a loss of $30 \%$, due to the consideration of the demand. Then, the revenue will be :

$1,50 X Y$ Therefore, the actual profit will be $50 \%$ of the total costs.

Thus, the proportion of gain from the sale of the product treated with respect to the non-treated, will be: $1,50 X Y / 1,05 X Y=1,4286$ which means $42.86 \%$ more in revenue and a profit ten times higher than for the tomato treaty.

This difference of $42.86 \%$ of revenue caused by the loss of quality of tomatoes not treaty was due to the loss of $30 \%$ of active (MARION 1996), i.e. , those $30 \%$ of tomatoes not sold caused a difference of $42.86 \%$ in revenue and, to compensate for this value, the trader should increase the price to the consumer in $142.86 \%$, which would be practically impossible. In this case, the company would not have price advantage with competitors.

The time is another important factor in the analysis of this simulation, since the product without treatment is lost 
within a week. This means that a new application must be generated before the end of the period for which, in the next week, has product available to the customer, which will incur new costs for the next period. Already the tomato treaty has a cycle of survival of two weeks, the requests can be made every two weeks, which will mean in other economies as transport, generation of requests, etc.

With this analysis, it can be seen that with an appropriate treatment, such as ozonation, in order to extend the period of storage, the trader of tomato will have competitive advantage in terms of costs and profits and competitive advantage to have a differentiated product (PORTER 1989) of other competitors, thereby keeping the margin in the value chain, in addition to avoid losses in the productive chain of tomatoes.

\section{Final Considerations}

This research work showed that there was no creation of value and competitive advantage in logistics of post-harvest treatment of tomato with the application of ozone gas in copies of tomato cultivar Deborah in the period of storage.

The survival time of ozonized tomato was increased in seven days in relation to the untreated. The concentration of ozone at $1 \mathrm{ppm}$ vol for 24 hours at $25{ }^{\circ} \mathrm{C} \pm 3{ }^{\circ} \mathrm{C}$ and $85 \% \pm 10 \%$ of relative humidity showed efficiency regarding the metric mass loss, senescence, injuries, vitamin $\mathrm{C}$ content and $\mathrm{pH}$. As to the degree of ripeness, showed satisfactory result if compared with fruit not treated.

The impact on the value chain of the tomato was considerable, there is a view that the product treated with ozone obtained an increase of life post-harvest a week, causing merchants industry acquire competitive advantage in logistics of storage by have a differentiated product of competitors.

Whereas the research was performed at the level of laboratory, has as a limitation of this work the non-application of this experiment on a large scale, as well as the calculations of the costs for the implementation of this type of treatment. We suggest that future work in this area for the determination of real gains in agribusiness if this technology could be expanded to other sectors of food.

\section{References}

Association of Official Analytical Chemistry. Official methods of analysis of the association of official analytical chemistry 16 ed., 1977. $1115 p$.

Batalha, Mário Otávio (coordenador). Gestão agroindustrial: GEPAl: Grupo de estudos e pesquisas agroindustriais. 3. Ed. São Paulo: Atlas, 2007.

Bialka, Katherine L.; Demirci, Ali. Utilization of Gaseous Ozone for the Decontamination of Escherichia coli 0157:H7 and Salmonella on Raspberries and Strawberries. Journal of Food Protection. May 2007, v. 70, issue 5, p. 1093-1098.

Bowersox, Donald J. Closs, David J. Logística Empresarial: 0 processo de integração da cadeia de suprimentos. 1 ed., São Paulo: ATLAS, 2001.

BRAGA, Newton c. Motor iônico. Saber Eletrônica, n. 166, p. 6. São Paulo: SABER, ago. 1986.

Carvalho, C. R. L. et al. Análises químicas de alimentos (Manual Técnico). Campinas: Biblioteca do Ital,1990.

Ceagesp e Secretaria de Agricultura e Abastecimento do Estado de São Paulo. Classificação de tomate. Programa Horti \& Fruti Programa paulista para a melhoria dos padrões comerciais e embalagens de hortigranjeiros, 1998 (folheto).

Davis, Mark M. Fundamentos da Administração da Produção. 3. ed. Porto Alegre: Bookman Editora, 2001.

Ferreira, Marcos David. Perdas na cadeia produtiva do tomate. Campinas: Feagri/UNICAMPI, 2003.

Ferreira M.D; Franco A.T.O; Ferraz A.C.O; Camargo G.G.T; TAVARES, M. Qualidade do tomate de mesa em diferentes etapas da fase de pós-colheita. Horticultura Brasileira n. 26, p: 231-235, 2008.

Gaither, Norman. Administração da Produção e operações. 8. ed. São Paulo: Pioneira Thomson Learning, 2002.

Luengo, R.F.A.; Calbo, A.G. Armazenamento de hortaliças. Brasília: Embrapa Hortaliças, 2001. 242 p.

Marion, José Carlos (coordenador). Contabilidade e Controladoria em Agribusiness. São Paulo: Atlas, 1996.

Nottingham, Oliver Castro e Silva. Projeto e construção de um gerador de ozônio de baixo consumo para aplicações de pequeno porte. $22^{\circ}$ Congresso Brasileiro de Engenharia Sanitária e Ambiental. Santa Catarina, 2003.

Palou, L. Smilanick, J.L. Crisosto, C.H. Mansour, M. Effect of Gaseous Ozone Exposure on the Development of Green and Blue Molds on Cold Stored Citrus Fruit. Plant Disease. June 2001, v. 85, n. 6, p. 632-638.

Porter, Michael E. Vantagem competitiva: criando e sustentando um desempenho superior. Rio de Janeiro: Campus, 1989.

Puia, Carmen; Oroian, I.; Florian, V. Effect of Ozone Exposure on Phytopathogenic Microorganisms on Stored Apples. Journal of Agricultural Sciences. 2004, 15, p 9-13.

Rice, R.G.; Farquhar, W. and Bollyky, L.J.. Review of the application of ozone for increasing storage time for perishable foods. Ozone Sci. Eng. 4(1): 147-163. 1982

Salvador, Alejandra; Abad, Isabel; Arnal, Lucía; Martínez-Jávega, J.M. Effect of Ozone on Postharvest Quality of Persimmon. Journal of Food Science, v. 71, n. 6, August 2006 , pp. S443-S446(1). 
Silva, Fred B. Conceitos e diretrizes para a gestão da logística no processo de produção de edifícios. Dissertação de mestrado. EPUSP, 2000.

Silveira, Teniza da; Evrard, Yves. Um estudo sobre a gestão do conhecimento sobre valor para o cliente em grandes empresas brasileiras. In: ENANPAD - Encontro Anual da Associação de Programas de Pós-Graduação em Administração de Empresas, 26., 2002, Salvador. Anais...Salvador: ANPAD, 2002.

Xu, Liangji. Use of ozone to improve the safety of fresh fruits and vegetables. Food technology. vol. 53, n.10, p. 58-63. 1999.

Zylberzstajn, Décio; Neves, Marcos Fava (organizadores). Economia \& Gestão dos Negócios Agroalimentares. São Paulo: Pioneira, 2000. 